\title{
Perubahan Komposisi Kimiawi Produk Yogurt dengan Penambahan Kalsium Karbonat pada Kultur Starter Campuran
}

\author{
Agus Safari $^{1)}$, Sarah Fahma Ghina ${ }^{1)}$, Sadiah Djajasoepena ${ }^{1}$, O. Suprijana ${ }^{1)}$, \\ Ida Indrawati ${ }^{2)}$, Saadah D. Rachman ${ }^{1)}$, Dian S. Kamara ${ }^{1)}$, dan Safri Ishmayana ${ }^{1 *)}$ \\ ${ }^{1}$ Departemen Kimia, Fakultas Matematika dan Ilmu Pengetahuan Alam, Universitas Padjadjaran, \\ Jalan. Raya Bandung, Sumedang km. 21 Jatinangor, Sumedang, Jawa Barat 45363 \\ ${ }^{2}$ Departemen Biologi, Fakultas Matematika dan Ilmu Pengetahuan Alam, Universitas Padjadjaran, \\ Jalan Raya Bandung, Sumedang km. 21 Jatinangor, Sumedang, Jawa Barat 45363 \\ Diterima 03-11-2016 Disetujui 13-12-2016
}

\begin{abstract}
Mixed lactic acid bacteria culture is commonly used in yogurt production. In the present study, two lactic acid bacteria (Lactobacillus bulgaricus and Streptococcus thermophillus) was used as starter culture. Calcium carbonate was added to the starter culture to increase the quality of mixed starter culture of L. bulgaricus and S. thermophillus with ratio of 4:1. The present study was directed to investigate the chemical composition of mixed starter culture with and without calcium carbonat addition. Furthermore, the effect of each starter culture on yogurt product chemical composition was also examined. The $\mathrm{pH}$, lactose, soluble protein and acid content was determined as chemical composition parameters. For starter culture without calcium carbonate addition, the yogurt has $\mathrm{pH}$, lactose, soluble protein and acid content of 4.18-4.39, 4.18-4.39\% $\mathrm{w} / \mathrm{v}, 2.88-4.36 \% \mathrm{w} / \mathrm{v}$ and $0.82-0.99 \% \mathrm{w} / \mathrm{v}$, respectively. While for starter culture with calcium carbonate addition, the yogurt product has $\mathrm{pH}$, lactose, soluble protein and acid content of $4.26-4.37,1.47-1.75 \% \mathrm{~b} / \mathrm{v}, 3.42-4.95 \% \mathrm{w} / \mathrm{v}$ and $0.86-1.11 \% \mathrm{w} /$ $\mathrm{v}$, respectively. Addition of $0.05 \% \mathrm{w} / \mathrm{v}$ calcium carbonate to mixed starter culture gave effect on lactose consumption, where it still can convert lactose to lactic acid up to 45 days of storage. Furthermore, the yogurt product made with starter culture with calcium carbonate addition has higher soluble protein content compared to yogurt made with starter culture without calcium carbonate addition.
\end{abstract}

Keywords: calcium carbonate, Lactobacillus bulgaricus, mixed starter culture, Streptococcus thermophillus

\begin{abstract}
ABSTRAK
Penggunaan kultur campuran bakteri asam laktat pada proses pembuatan yogurt telah umum digunakan. Pada penelitian ini digunakan dua bakteri, yaitu Lactobacillus bulgaricus dan Streptococcus thermophillus sebagai bakteri kultur starter. Kalsium karbonat ditambahkan ke dalam kultur starter untuk meningkatkan kualitas kultur starter campuran bakteri $L$. bulgaricus dan S. thermophillus dengan perbandingan 4:1. Tujuan dari penelitian ini adalah untuk mengetahui komposisi kimiawi dari kultur starter campuran dengan dan tanpa penambahan kalsium karbonat serta mempelajari pengaruh penambahan kalsium karbonat terhadap komponen kimiawi produk yogurt yang dihasilkan. Parameter yang ditentukan meliputi nilai pH, kadar laktosa, kadar protein terlarut dan kadar asam. Hasil penelitian ini menunjukkan bahwa produk yogurt yang dihasilkan dengan menggunakan kultur starter tanpa penambahan kalsium karbonat memiliki pH 4,18-4,39; kadar laktosa 4,18-4,39\% $\mathrm{b} / \mathrm{v}$; kadar asam $0,82-0,99 \% \mathrm{~b} / \mathrm{v}$ dan kadar protein terlarut $2,88-4,36 \% \mathrm{~b} / \mathrm{v}$. Sedangkan produk yogurt yang dibuat menggunakan kultur starter dengan penambahan kalsium karbonat memiliki pH 4,26-4,37; kadar laktosa 1,47-1,75\% b/v; kadar asam $0,86-1,11 \% \mathrm{~b} / \mathrm{v}$ dan kadar protein terlaurt 3,42-4,95\% b/v. Penambahan kalsium karbonat dengan konsentrasi akhir $0.5 \% \mathrm{~b} / \mathrm{v}$ pada kultur starter campuran memberikan pengaruh terhadap kadar laktosa produk yogurt yang dihasilkan,
\end{abstract}

*Telp: +62817617136

Email: ishmayana@gmail.com 
dimana kultur starter campuran yang ditambahkan kalsium karbonat masih mampu mengubah laktosa menjadi asam laktat dengan baik sampai masa simpan 45 hari. Selain itu, produk yogurt yang dihasilkan dari kultur starter campuran dengan penambahan kalsium karbonat memiliki kandungan protein terlarut yang lebih tinggi dibandingkan produk yogurt dari kultur yang tidak ditambah dengan kalsium karbonat.

Kata Kunci: kalsium karbonat, kultur starter campuran, Lactobacillus bulgaricus, Streptococcus thermopohillus

\section{PENDAHULUAN}

Yogurt sebagai salah satu produk hasil olahan susu dibuat melalui proses fermentasi susu dengan bantuan bakteri asam laktat, diantaranya adalah Lactobacillus bulgaricus dan Streptococcus thermophillus. Kedua bakteri ini berperan sebagai bakteri asam laktat yang berperan mengubah laktosa dalam susu menjadi asam laktat dan juga umum digunakan dengan mencampurkan keduanya dalam kultur starter tersebut (Özen \& Özilgen 1992; Herve-Jimenez et al. 2009; Rachman et al. 2015). Proses fermentasi pada pembuatan yogurt dimulai dengan hidrolisis laktosa menjadi glukosa dan galaktosa. Glukosa dimetabolisme melalui jalur glikolisis menjadi asam piruvat untuk kemudian diubah menjadi asam laktat. Glukosa yang dihasilkan dari hidrolsis laktosa juga memasuki jalur glikolisis melalui galaktosa-1-fosfat, glukosa-1-fosfat akhirnya membentuk glukosa-6-fosfat yang merupakan salah satu intermediet pada reaksi glikolisis (Abdel-Rahman et al. 2013).

Penelitian sebelumnya menunjukkan bahwa penambahan $10 \%$ v/v kultur starter campuran L. bulgaricus dan S. thermophillus dengan perbandingan 1:1 dan 4:1 pada susu skim menghasilkan produk yogurt dengan komposis kimiawi terbaik (Kania 2001). Untuk mengembangkan kultur terbaik ini, maka diperlukan penambahan suplemen lain ke dalam campuran kutur starter sehingga dapat meningkatkan daya tahan kultur starter. Hal ini diperlukan karena aktivitas bakteri asam laktat yang terdapat dalam kultur starter menurun seiring dengan berjalannya waktu sehingga menyebabkan kultur starter campuran tidak dapat disimpan dalam jangka waktu yang lama ( \pm 2 minggu).

Berbagai upaya dilakukan untuk mempertahankan aktivitas BAL diantaranya dengan menambahkan lioprotektan dan proses liofilisasi ataupun dengan metode spray dry (Strasser et al. 2009; Peighambardoust et al.
2011). Pada penelitian ini dilakukan penambahan kalsium karbonat sebagai suplemen untuk meningkatkan daya tahan bakteri selama proses penyimpanan. Suslow \& Schroth (1981) menemukan bahwa penggunaan kalsium karbonat dalam media yeast dextrose calcium carbonate peptone agar dapat mempertahankan aktivitas bakteri sampai waktu 8 bulan. Kang et al.(1985) juga melaporkan bahwa penggunaan kalsium karbonat dapat menjaga aktivitas Lactobacillus acidophilus selama 150 hari pada suhu penyimpanan $37^{\circ} \mathrm{C}$ dan kultur yogurt dapat tetap aktif selama 150 hari pada suhu penyimpanan $0^{\circ} \mathrm{C}$. Marković et al. (2011) membuktikan bahwa penambahan kalsium karbonat dapat melindungi dan menjaga tingkat viabilitas bakteri. Selain itu, Yang et al. (2015) melaporkan bahwa penambahan kalsium karbonat dapat meningkatkan produksi asam laktat pada proses fermentasi dengan menggunakan Lactobacillus lactis. Oleh karena itu pada penelitian ini akan dilakukan penambahan kalsium karbonat untuk mempelajari pengaruhnya terhadap aktivitas kultur starter dan produk yogurt yang dihasilkan.

\section{BAHAN DAN METODE}

Alat-alat yang digunakan pada penelitian ini adalah autoclave, ruang steril, pembakar Bunsen, lemari pendingin, spektrofotometer UV-vis Jenway 6105, pH meter Mettler Toledo MP220, sentrifugasi Beckman TJ-6, peralatan titrasi, penangas air dan alat-alat gelas yang umum digunakan di laboratorium.

Bahan yang digunakan dalam penelitian ini adalah biakan bakteri murni L. bulgaricus yang diperoleh dari jurusan Biologi ITB dan S. thermophillus yang diperoleh dari laboratorium mikrobiologi jurusan teknik kimia ITB, ekstrak ragi, bakto pepton, glukosa, susu skim, susu murni yang diperoleh dari laboratorium produksi ternak Universitas Padjadjaran, asam sulfat, asam oksalat, natrium tungstat, tembaga-alkalis, kalsium karbonat, fosfomolibdat, 
natrium karbonat, natrium hidroksida, tembaga sulfat pentahidrat, natrium-kalium tartarat, larutan FolinCiocalteu, dan fenolftalein.

Pembuatan Kultur Starter Tunggal. Sebanyak $50 \mathrm{~mL}$ susu skim yang telah dipasteurisasi pada suhu $80-90^{\circ} \mathrm{C}$ selama 20 menit di dalam labu Erlenmeyer diinokulasi dengan satu ose L. bulgaricus. Labu Erlenmeyer kedua diinokulasi dengan satu ose $S$. thermophillus. Kedua labu Erlemneyer kemudian dihomogenisasi dan diinkubasi selama 24 jam pada suhu $42^{\circ} \mathrm{C}$ dan kemudian disimpan di lemari pendingin dengan suhu $4^{\circ} \mathrm{C}$. Kultur ini digunakan dalam waktu 24 jam untuk membuat kultur starter campuran.

Pembuatan Kultur Starter Campuran. Sebanyak 100 $\mathrm{mL}$ susu skim dalam labu Erlenmeyer dipasteurisasi pada suhu $80-90^{\circ} \mathrm{C}$ selama 20 menit. Setelah dingin sebanyak 8 $\mathrm{mL}$ kultur starter tunggal L. bulgaricus dan $2 \mathrm{~mL}$ kultur starter tunggal $S$. thermophillus ditambahkan ke dalam susu yang telah dipasteurisasi. Selanjutnya diinkubasi pada suhu $42^{\circ} \mathrm{C}$ selama 24 jam dan disimpan dalam lemari pendingin pada suhu $4^{\circ} \mathrm{C}$. Kultur ini digunakan dalam waktu 24 jam untuk membuat kultur starter campuran.

Pembuatan Kultur Starter Campuran dengan Penambahan Kalsium Karbonat. Dua buah labu Erlenmeyer disiapkan dan kedalamnya dimasukkan sebanyak $10 \mathrm{~g}$ susu skim. Setelah itu, ditambahkan kalsium karbonat sebanyak 0,5 g ke dalam salah satu labu Erlenmeyer sehingga mencapai konsentrasi akhir $0,5 \% \mathrm{~b} / \mathrm{v}$ pada larutan, sedangkan labu Erlenmeyer yang lain tidak ditambah dengan kalsium karbonat. Kemudian ditambahkan air suling sebanyak $100 \mathrm{~mL}$ dan dipasteurisasi pada suhu $80-90^{\circ} \mathrm{C}$ selama 20 menit. Setelah mencapai $\pm 40^{\circ} \mathrm{C}$ diinokulasi dengan kultur starter campuran $L$. bulgaricus dan $S$. thermophillus yang telah dibuat sebelumnya. Campuran kemudian diinkubasi pada suhu $42^{\circ} \mathrm{C}$ selama 24 jam dan selanjutnya disimpan pada lemari pendingin dengan suhu $4^{\circ} \mathrm{C}$. Kultur starter ini digunakan untuk membuat yogurt setelah disimpan selama 1, 15, 30, dan 45 hari.

Pembuatan Yogurt. Susu segar yang akan difermentasi dipasteurisasi terlebih dahulu dengan pemanasan $80-90^{\circ} \mathrm{C}$ selama 20 menit. Susu tersebut dimasukkan ke dalam dua labu Erlenmeyer dan ke dalamnya dimasukkan kultur starter campuran yang telah dibuat sebanyak $10 \%$ dari volume susu. Satu labu ditambahkan dengan kultur starter yang diberi kalsium karbonat, sedangkan labu yang lain diberi kultur starter tanpa penambahan kalsium karbonat. Selanjutnya dikocok dan diinkubasi pada suhu $42^{\circ} \mathrm{C}$ selama 8 jam. Pembuatan yogurt dilakukan selama masa penyimpanan kultur starter, yaitu pada hari ke-1, 15, 30, dan 45.

Pengukuran pH. Nilai pH sampel ditentukan dengan menggunakan $\mathrm{pH}$ meter digital pada suhu kamar

Penentuan Kadar Asam. Kadar asam ditentukan dengan metode titrasi asam-basa menggunakan indikator fenolftalein sesuai dengan prosedur yang dikemukakan oleh Wahyudi (2006). Sebanyak $10 \mathrm{~mL}$ sampel diambil dengan pipet, dimasukkan ke dalam labu Erlenmeyer dan ditambahkan dengan 2 tetes larutan indikator fenolftalein. Larutan sampel kemudian dititrasi dengan larutan natrium hidroksida yang telah distandarisasi terlebih dahulu, sampai diperoleh perubahan warna menjadi merah muda. Total asam dihitung sebagai persentase asam laktat dan dihitung dengan persamaan (1).

$$
\text { Kadar asam laktat }(\%)=\frac{\mathrm{A} \times \mathrm{B} \times 0,009 \times 100}{\mathrm{C}}
$$

$$
\begin{array}{lll}
\operatorname{dimana} & \mathrm{A}= & \text { Volume } \mathrm{NaOH}(\mathrm{mL}) \\
& \mathrm{B}= & \text { Normalitas } \mathrm{NaOH}(\mathrm{N}) \\
& \mathrm{C}= & \text { Volume sampel }(\mathrm{mL})
\end{array}
$$

Pengukuran Kadar Laktosa. Kadar laktosa dalam sampel diukur dengan menggunakan metode kolorimetri sesuai yang dijelaskan oleh Somogyi (1952) dan Nelson (1944). Sebanyak $1 \mathrm{~mL}$ sampel dimasukkan ke dalam labu ukur $100 \mathrm{~mL}$, ditambahkan dengan $2 \mathrm{~mL}$ asam sulfat $0,3 \mathrm{M}$ dan $2 \mathrm{~mL}$ natrium-tungstat $10 \%$. Diencerkan sampai tanda batas dengan air suling, kemudian larutan disentrifugasi dengan kecepatan 3000 RPM selama 15 menit. Supernatan dipisahkan dengan endapannya kemudian dimasukkan ke dalam tabung reaksi sebanyak $1 \mathrm{~mL}$ dan ditambah dengan $1 \mathrm{~mL}$ air suling. Untuk blanko digunakan $2 \mathrm{~mL}$ air suling dalam tabung reaksi, sedangkan untuk standar digunakan $1 \mathrm{~mL}$ larutan standar laktosa dengan konsentrasi $0,3 \mathrm{mg} / \mathrm{mL}$ dan ditambahkan juga $1 \mathrm{~mL}$ air suling. Ke dalam masing-masing tabung reaksi ditambahkan $2 \mathrm{~mL}$ reagen tembaga alkalis Nelson-Somogyi, kemudian dipanaskan dalam penangas air mendidih selama 8 menit. Tabung 
didinginkan dan ditambahkan dengan $4 \mathrm{~mL}$ reagen fosfomolibdat, dikocok dan didiamkan selama 1 menit. Setelah itu masing-masing isi tabung reaksi dipindahkan ke dalam labu ukur $25 \mathrm{~mL}$ dan campuran reaksi diencerkan dengan asam fosfomolibdat yang diencerkan 5 kali sehingga mencapai batas. Serapan diukur dengan menggunakan spektrofotometer UV-vis pada panjang gelombang $630 \mathrm{~nm}$. Kadar laktosa ditentukan dengan cara membandingkan nilai absorban sampel dengan standar yang telah diketahui konsentrasinya.

Penentuan Kadar Protein Terlarut. Penentuan kadar protein dilakukan dengan metode yang dijelaskan oleh Lowry et al. (1951). Sebanyak 0,1 mL larutan standar BSA $(0,00 ; 0,5 ; 1,0 ; 2,0 ; 3,0 ; 4,0$ dan $5,0 \mathrm{mg} / \mathrm{mL})$ atau sampel yang akan ditentukan kadar proteinnya dimasukkan ke dalam tabung reaksi. Kemudian ditambahkan sebanyak $5 \mathrm{~mL}$ pereaksi Lowry C $(50 \mathrm{~mL} 2 \%$ natrium karbonat dalam $0,1 \mathrm{~N}$ natrium hidroksida : $1 \mathrm{~mL} 0,5 \%$ tembaga sulfat pentahidrat dalam $1 \%$ natrium tartrat) dan didiamkan selama 10 menit. Sebanyak 0,5 mL larutan Folin-Ciocalteu kemudian ditambahkan, dikocok dan didiamkan selama 30 menit. Serapan diukur pada panjang gelombang $750 \mathrm{~nm}$ dengan menggunakan spektrofotometer. Hasil pengukuran serapan standar dibuat kurva baku, dan serapan sampel diplotkan pada kurva baku tersebut untuk menghitung konsentrasi protein yang terkandung dalam sampel.

\section{HASIL DAN PEMBAHASAN}

Parameter Kimiawi Susu Skim dan Susu Murni.

Sebagai data awal sebelum dilakukan proses fermentasi, kadar laktosa dan protein susu skim dan susu murni

Tabel 1 Kandungan laktosa dan protein susu skim dan susu murni yang digunakan pada penelitian ini

\begin{tabular}{lcc}
\hline \multicolumn{1}{c}{ Sampel } & $\begin{array}{c}\text { Kadar Laktosa } \\
(\% \mathrm{~b} / \mathrm{v})\end{array}$ & $\begin{array}{c}\text { Kadar Protein } \\
(\% \mathrm{~b} / \mathrm{v})\end{array}$ \\
\hline Susu Skim 10\% (b/v) & 5,30 & 2,36 \\
Susu Murni & 4,87 & 2,59 \\
\hline
\end{tabular}

ditentukan dan hasilnya ditunjukkan pada Tabel 1. Data ini akan dibandingkan dengan kultur starter campuran dan juga yogurt yang dibuat dengan menggunakan kultur starter campuran.

Kualitas Kultur Starter Tunggal. Untuk mengetahui apakah kultur starter tunggal hasil inokulasi L. bulgaricus dan $S$. thermophillus memiliki aktivitas yang baik ataukah tidak, parameter yang diamati adalah nilai $\mathrm{pH}$ media susu skim $10 \%$ b/v. Hal ini dilakukan karena aktivitas kedua bakteri mengubah laktosa menjadi asam laktat sehingga menurunkan $\mathrm{pH}$ media susu yang digunakan sebagai media tumbuh.

Media susu skim $10 \% \mathrm{~b} / \mathrm{v}$ memiliki nilai $\mathrm{pH}$ awal sebesar 6,33 dan setelah diinokulasi dengan L. bulgaricus ataupun $S$. thermophillus dan diinkubasi pada suhu $42^{\circ} \mathrm{C}$ selama 24 jam, nilai $\mathrm{pH}$ mengalami penurunan masingmasing menjadi 4,13 dan 4,21. Berdasarkan parameter $\mathrm{pH}$ yang terukur, maka kultur starter tunggal L. bulgaricus dan S. thermophillus yang dibuat termasuk kriteria kultur starter yang baik karena nilainya masih berada di sekitar rentang 3,80-4,60 yang merupakan nilai $\mathrm{pH}$ yang baik untuk kultur starter (Marshall 1987).

Kualitas Kultur Starter Campuran. Kultur starter campuran dibuat dengan mencampurkan 4 bagian kultur tunggal L. bulgaricus dan 1 bagian kultur tunggal $S$. thermophillus. Pengukuran parameter $\mathrm{pH}$, kadar asam, kadar protein dan kadar laktosa dilakukan terhadap kultur starter campuran tanpa penambahan kalsium karbonat ataupun dengan penambahan kalsium karbonat. Hasil pengukuran parameter tersebut ditunjukkan pada Tabel 2.

Nilai $\mathrm{pH}$ merupakan salah satu parameter penting untuk menentukan apakah suatu kultur starter memiliki aktivitas yang masih baik. Dijadikanya nilai $\mathrm{pH}$ sebagai salah satu parameter aktivitas kultur starter adalah karena pengubahan laktosa menjadi asam laktat oleh bakteri sehingga meningkatkan tingkat keasaman susu sehingga nilai $\mathrm{pH}$ menjadi turun. Sesuai dengan kategori yang

Tabel 2 Hasil penentuan komposisi kimiawi kultur starter campuran

\begin{tabular}{ccccc}
\hline $\begin{array}{c}\text { Konsentrasi kalsium karbonat } \\
(\% \mathrm{~b} / \mathrm{b})\end{array}$ & $\mathrm{pH}$ & $\begin{array}{c}\text { Kadar laktosa } \\
(\% \mathrm{~b} / \mathrm{v})\end{array}$ & $\begin{array}{c}\text { Kadar protein } \\
(\% \mathrm{~b} / \mathrm{v})\end{array}$ & $\begin{array}{c}\text { Kadar asam } \\
(\% \mathrm{~b} / \mathrm{v})\end{array}$ \\
\hline 0 & 4,12 & 1,60 & 3,23 & 0,97 \\
0,5 & 4,32 & 1,32 & 3,34 & 0,89 \\
\hline
\end{tabular}


diungkapkan oleh Marshall (1987) maka kedua kultur starter campuran termasuk kategori yang baik.

Parameter yang kedua adalah kadar laktosa. Kadar laktosa kultur starter tanpa penambahan kalsium karbonat adalah $1,60 \% \mathrm{~b} / \mathrm{v}$ sedangkan dengan penambahan kalsium karbonat adalah $1,32 \% \mathrm{~b} / \mathrm{v}$. Penentuan baik atau tidaknya aktivitas kultur starter ditunjukkan dengan adanya penurunan kadar laktosa dibandingkan dengan kadar laktosa awal susu skim sebagai media kultur. Kadar laktosa susu skim adalah sebesar 5,30\% b/v. Oleh karena itu, kedua kultur starter campuran menunjukkan adanya penurunan kadar laktosa. Kedua bakteri yang digunakan pada penelitian ini termasuk golongan bakteri homofermentatif (Tamime \& Robinson 2007), yang berarti kedua bakteri tersebut memiliki kemampuan untuk mengubah $100 \%$ laktosa menjadi asam laktat. Oleh karena itu terjadi penurunan kadar laktosa seperti yang telah dijelaskan sebelumnya.

Kultur starter yang baik juga akan mengalami peningkatan kadar protein total dibandingkan dengan media awal susu skim (Tamime \& Robinson 2007). Selain itu, penelitian yang dilakukan oleh Tsai et al. (2008) menunjukkan bahwa kadar potein terlarut produk yogurt yang difermentasi dengan kultur campuran L. bulgaricus dan $S$. thermophillus yang diukur dengan metode Lowry juga meningkat dari 4,9 menjadi $5,5 \mathrm{mg} / \mathrm{g}$. Hasil yang dipaparkan oleh Tsai et al. (2008) sesuai dengan hasil penelitian ini. Kadar protein susu skim yang digunakan adalah $2,36 \% \mathrm{~b} / \mathrm{v}$, sedangkan kultur starter tanpa penambahan kalsium karbonat memiliki kadar protein sebesar 3,23\% b/v sedangkan dengan penambahan kalsium karbonat kadar protein terdeteksi sebesar 3,34\% b/v. Terjadinya peningkatan kadar protein terlarut kemungkinan terjadi karena bakteri yang digunakan pada proses fermentasi memproduksi protein terlarut. Sehingga meskipun protein utama pada susu (kasien) mengendap karena terjadi penurunan $\mathrm{pH}$, namun kadar protein terlarut meningkat karena bertambahnya protein terlarut yang dihasilkan oleh kultur bakteri. Selain itu penambahan kalsium karbonat juga meningkatkan kadar protein terlarut, yang kemungkinan disebabkan karena peranan kalsium karbonat dalam meningkatkan aktivitas fermentasi bakteri (Marković et al. 2010). Data kadar protein yang diperoleh menunjukkan aktivitas yang baik.

Kadar asam diasumsikan sebagai kadar asam total yang terdiri dari sebagian besar asam laktat dam sebagian kecil asam organik lain sebagai produk samping dari metabolisme bakteri. Kadar asam kultur starter tanpa penambahan kalsium karbonat mencapai $0,97 \%$ b/v sedangkan dengan penambahan kalsium karbonat nilai kadar asam sebesar 0,89\% b/v. Nilai kadar asam tersebut mendekati nilai yang diungkapkan literatur, yaitu sebesar 0,80-0,93\% b/v (Tamime \& Robinson 2007), bahkan pada kultur starter yang ditambah dengan kalsium karbonat nilanya masuk dalam rentang yang disarankan. Hal ini menunjukkan bahwa kultur starter yang telah dibuat memiliki aktivitas yang baik sehingga dapat digunakan untuk fermentasi yogurt.

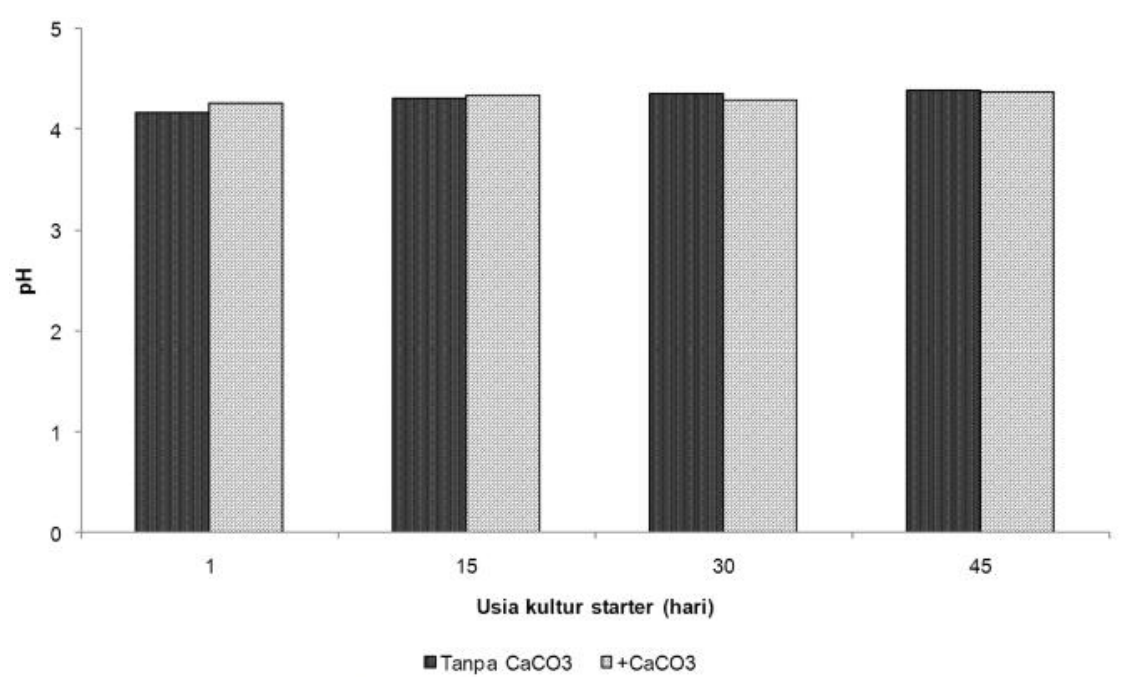

Gambar 1 Nilai pH produk yogurt yang dibuat dengan kultur starter yang memiliki waktu simpan yang berbeda 
Parameter Kimiawi Yogurt. Pembuatan yogurt dilakukan dengan selang waktu 15 hari masa penyimpanan kultur starter, yaitu pada hari ke-1, 15, 30 dan 45. Nilai pH, kadar laktosa, kadar asam dan kadar protein produk yogurt yang dihasilkan ditentukan.

Hasil penentuan $\mathrm{pH}$ ditunjukkan pada Gambar 1. Hasil yang diperoleh menunjukkan bahwa produk yogurt yang dihasilkan dengan menggunakan kultur starter yang disimpan selama 1 sampai dengan 45 hari memiliki rentang pH 4,18-4,39 yang masih termasuk dalam rentang nilai $\mathrm{pH}$ produk yogurt yang baik menurut. Menurut Jay (2000) produk yogurt yang baik memiliki nilai $\mathrm{pH}$ pada rentang 3,65-4,40. Nilai $\mathrm{pH}$ produk yogurt yang dibuat dengan menggunakan kultur starter yang telah disimpan selama 15,30 dan 45 hari memiliki nilai $\mathrm{pH}$ yang relatif sedikit lebih tinggi $(4,31-4,39)$ dibandingkan dengan yogurt yang dibuat dengan kuktur starter yang baru disimpan selama 1 hari (4,18 untuk kultur starter tanpa penambahan kalsium karbonat dan 4,26 untuk kultur starter dengan penambahan kalsium karbonat). Hal ini dapat terjadi karena aktivitas bakteri menurun seiring dengan berjalannya peningkatan masa simpan, meskipun perbedaanya tidak terlalu signifikan.

Hasil pengukuran kadar asam produk yogurt ditunjukkan pada Gambar 2. Kadar asam produk yogurt yang menggunakan kultur starter tanpa penambahan kalsium karbonat memberikan nilai antara 0,82 sampai dengan $0,99 \% \mathrm{~b} / \mathrm{v}$, sedangkan dengan penambahan kalsium karbonat nilai kadar asam yang terukur antara 0,86 sampai dengan $1,11 \%$ b/v. Nilai kadar asam yang baik menurut Jay (2000) adalah 0,85-0,95\% b/v. Dari data kadar asam, dapat diketahui bahwa hampir semua produk yang dihasilkan memiliki kadar asam yang baik. Secara teoritis, produk yang memiliki nilai $\mathrm{pH}$ yang rendah akan memiliki kadar asam yang lebih tinggi. Pada penelitian ini nilai $\mathrm{pH}$ tidak berbeda secara signifikan. Namun demikian, kadar asam menunjukkan adanya perbedaan. Hal ini dapat terjadi karena sifat buffer dari komponen-komponen susu (Tamime \& Robinson 2007), sehingga meskipun nlai $\mathrm{pH}$ tidak berbeda, kadar asam yang terukur dapat berbeda. Selain itu, Marković et al. (2010) menjelaskan bahwa kalsium karbonat memiliki efek perlindungan dan menjaga viabilitas sel bakteri, sehingga aktivitas bakteri tetap tinggi. Oleh karena itu, pada Gambar 2 terlihat bahwa produk yogurt yang menggunakan kultur starter yang diberi kalsium karbonat memiliki kadar asam lebih tinggi.

Produk yogurt yang dihasilkan dengan kultur starter tanpa penambahan kalsium karbonat pada hari ke-1 sampai dengan 30 memiliki rentang kadar laktosa 1,62 sampai dengan $2,18 \% \mathrm{~b} / \mathrm{v}$. Sedangkan penggunaan kultur starter dengan masa simpan 45 hari memberikan kadar laktosa sebesar 3,90\% b/v yang menunjukkan bahwa kadar laktosa hanya turun sebesar 19,9\% dibandingkan dengan kadar laktosa susu murni yang digunakan. Sedangkan produk

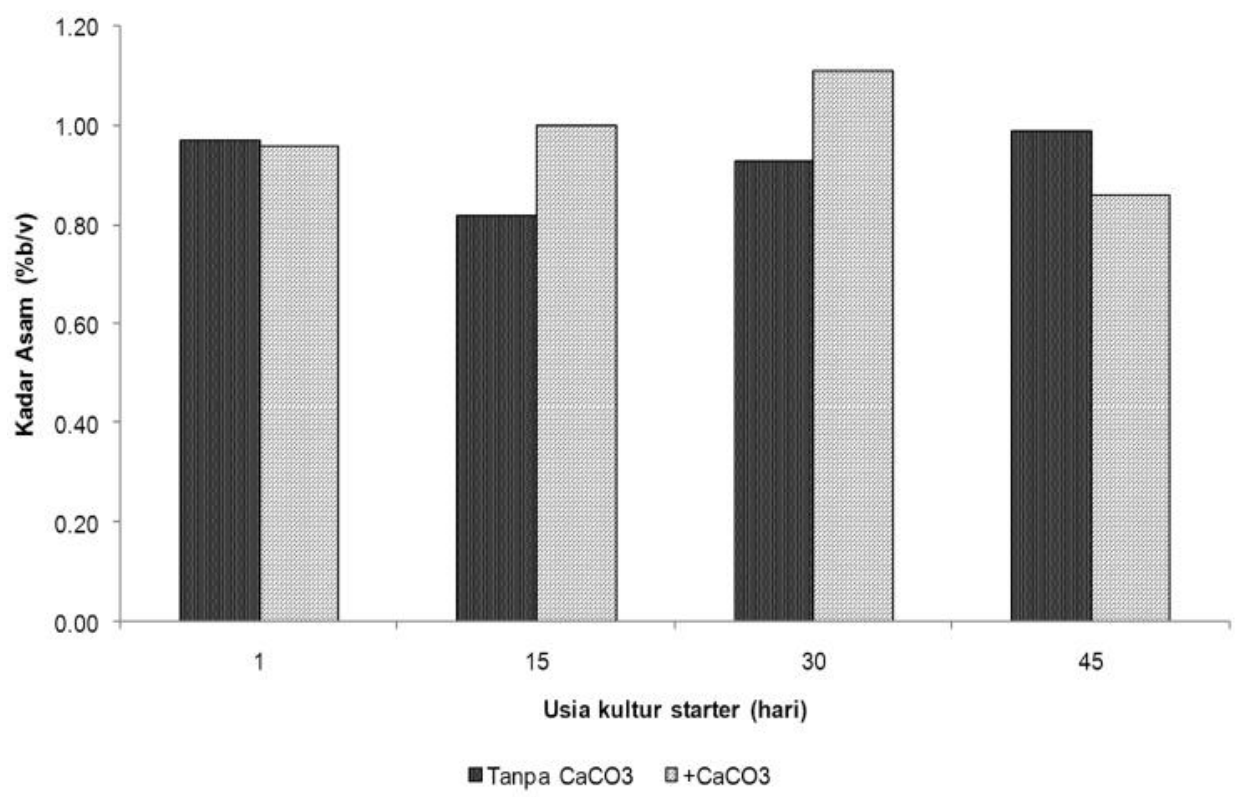

Gambar 2 Kadar asam produk yogurt yang dibuat dengan kultur starter yang memiliki waktu simpan yang berbeda 


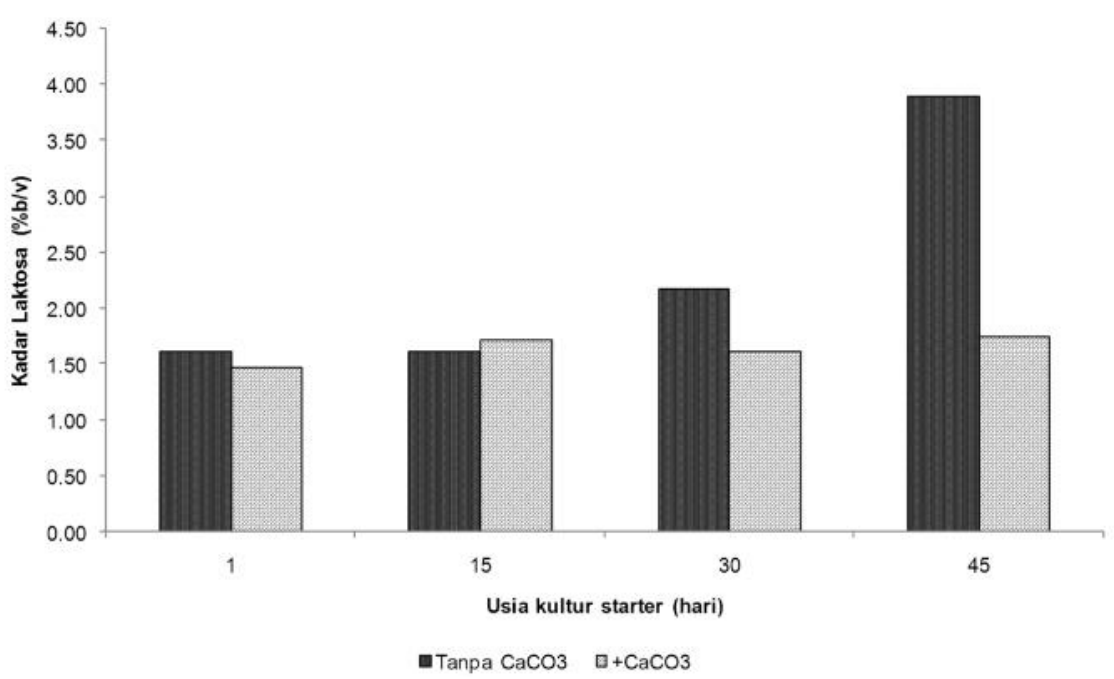

Gambar 3 Kadar laktosa produk yogurt yang dibuat dengan kultur starter yang memiliki waktu simpan yang berbeda

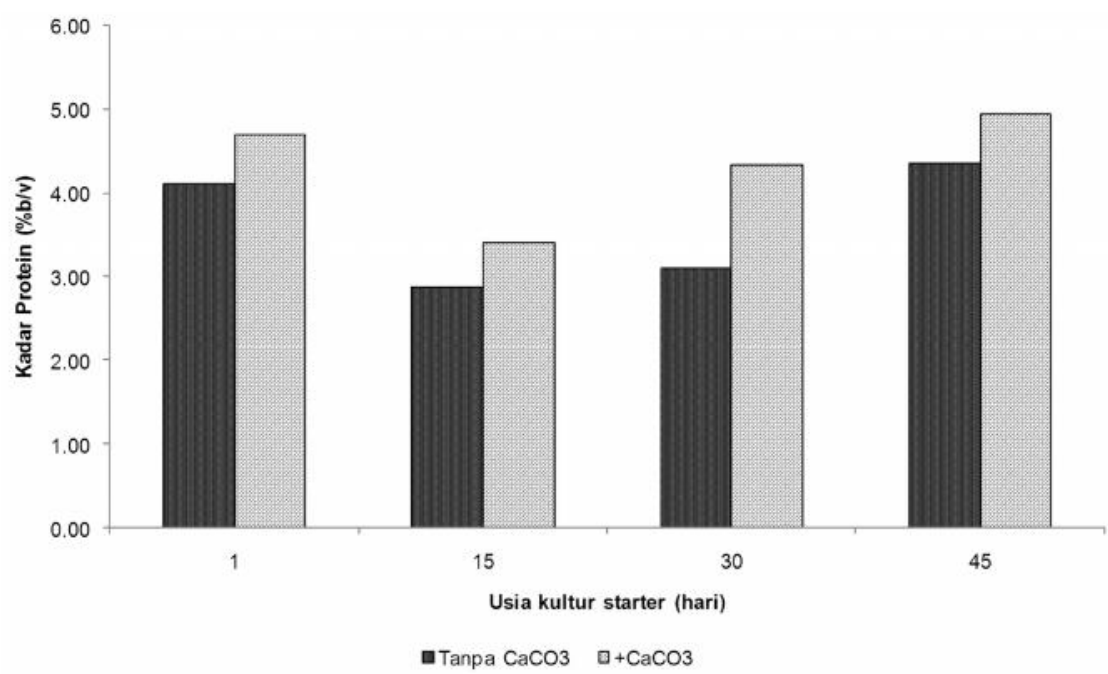

Gambar 4 Kadar protein produk yogurt yang dibuat dengan kultur starter yang memiliki waktu simpan yang berbeda

yogurt yang dibuat dengan menggunakan kultur starter yang ditambah dengan kalsium karbonat memiliki rentang kadar laktosa sebesar 1,47 sampai dengan $1,75 \%$ b/v. Dengan berkurangnya kadar laktosa tersebut menunjukkan bahwa dengan penambahan kalsium karbonat, sampai masa simpan selama 45 hari masih menunjukkan aktivitas yang baik. Data hasil pengukuran kadar laktosa ditunjukkan pada Gambar 3.

Hasil pengukuran kadar protein produk yogurt ditunjukkan pada Gambar 4. Kadar protein produk yogurt yang dibuat dengan kultur starter tanpa penambahan kalsium karbonat berkisar antara 2,89-4,36 \% b/v sedangkan produk yang dibuat dengan kultur starter yang ditambahkan kalsium karbonat memiliki nilai kadar protein antara 3,42-4,95. Dari data ini dapat terlihat bahwa produk yogurt yang dihasilkan dengan menggunakan kultur starter yang ditambah kalsium karbonat memiliki kadar protein yang lebih tinggi. Hal tersebut sesuai dengan pernyataan Tamime \& Robinson (2007) yang menyatakan bahwa ion kalsium membantu pembentukan gel protein dalam yogurt.

\section{SIMPULAN}

Penambahan kalsium karbonat pada kultur starter campuran memberikan pengaruh terhadap kadar laktosa dan kadar asam. Kadar laktosa produk yogurt menunjukkan bahwa kultur starter campuran yang disimpan selama 45 hari pada suhu $4^{\circ} \mathrm{C}$ masih memiliki aktivitas yang 
baik dalam mengubah laktosa susu menjadi asam laktat dibandingkan kultur starter campuran yang tidak ditambah dengan kalsium karbonat. Kadar protein produk yogurt menunjukkan kandungan protein yang lebih tinggi pada produk yogurt yang dibuat dengan kultur starter dengan penambahan kalsium karbonat.

\section{UCAPAN TERIMA KASIH}

Penulis mengucapkan terima kasih kepada Bpk. U. Juharia dan Bpk. Maman Tardi atas bantuan teknis yang telah diberikan.

\section{DAFTAR PUSTAKA}

Abdel-Rahman, M.A., Tashiro, Y \& Sonomoto, K. 2013. Recent advances in lactic acid production by microbial fermentation processes. Biotechnology Advances 31(6): 877-902.

Herve-Jimenez, L., Guillouard, I., Guedon, E., Boudebbouze, S., Hols, P., Monnet, V., Maguin, E \& Rul, F. 2009. Postgenomic analysis of Streptococcus thermophilus cocultivated in milk with Lactobacillus delbrueckii subsp. bulgaricus: Involvement of nitrogen, purine, and iron metabolism. Applied and Environmental Microbiology 75(7): 2062-2073.

Jay, J.M. 2000. Modern Food Microbiology, $6^{\text {th }}$ ed. Maryland: Aspen Publishers, Inc.,

Kang, K.H., Ahn, S.N \& Lee, J.Y. 1985. Dairy Science Abstract 47: 555.

Kania, N.R.E. 2001. Pembuatan kultur starter campuran (Lactobacillus bulgaricus dan Streptococcus thermophillus) yang unggul pada fermentasi yogurt. Skripsi. Jatinangor: Universitas Padjadjaran.

Lowry, O.H., Rosebrough, N.J., Farr, A.L \& Randall, R.J. 1951. Protein measurement with the Folin phenol reagent. Journal of Biological Chemistry 193: 265275.

Marković, M., Markov, M., Pejin, D., Mojović, L., Vukaśnović, M., Pejin, J \& J oković, N. 2011. The possibility of lactic acid fermentation in the triticale stillage. Chemical Industry \& Chemical Engineering Quarterly 17(2): 153-162

Marshall, V.M. 1987. Fermented milks and their future trends: I. Microbiological aspects. Journal of Dairy Research 54(4): 559-574.
Nelson, N. 1944. A photometric adaptation of the Somogyi method for the determination of glucose. Journal of Biological Chemistry 153: 375-380.

Özen, S. \& Özilgen, M. 1992. Effects of substrate concentration on growth and lactic acid production by mixed cultures of Lactobacillus bulgaricus and Streptococcus thermophilus. Journal of Chemical Technology and Biotechnology 54(1): 57-61.

Peighambardoust, S.H., Tafti, A.G \& Hesari, J. 2011. Application of spray drying for preservation of lactic acid starter cultures: a review. Trends in Food Science \& Technology 22(5): 215-224.

Rachman, S.D., Djajasoepena, S., Kamara, D.S., Idar, I., Sutrisna, R., Safari, A., Suprijana, O \& Ishmayana, S. 2015. Kualitas yoghurt yang dibuat dengan kultur dua (Lactobacillus bulgaricus dan Streptococcus thermophilus) dan tiga bakteri (Lactobacillus bulgaricus, Streptococcus thermophilus dan Lactobacillus acidophilus). Chimica et Natura Acta 3(2): 76-79.

Somogyi, M. 1952. Notes on sugar determination. Journal of Biological Chemistry 195: 19-23.

Strasser, S., Neureiter, M., Geppl, M., Braun, R \& Danner H. 2009. Influence of lyophilization, fluidized bed drying, addition of protectants, and storage on the viability of lactic acid bacteria. Journal of Applied Microbiology 107(1): 167-177.

Suslow, T.V \& Schroth, M.N. 1981. Bacterial culture preservation in frozen and dry-film methylcellulose. Applied and Environmental Microbiology 42(5): 872877.

Tamime, A.Y \& Robinson, R.K. 2007. Tamime and Robinson's Yoghurt Science and technology. 3rd ed. Cambridge: Woodhead Publishing.

Tsai, J.-S., Chen, T.-J., Pan, B.S., Gong, S.-D \& Chung, M.-Y. 2008. Antihypertensive effect of bioactive peptides produced by protease-facilitated lactic acid fermentation of milk. Food Chemistry 106(2): 552558.

Yang, P.-B., Tian, Y., Wang, Q \& Cong, W. 2015. Effect of different types of calcium carbonate on the lactic acid effect of different types of calcium carbonate on the lactic acid fermentation performance of Lactobacillus lactis. Biochemical Engineering Journal 98: 38-46.

Wahyudi, M. 2006. Proses pembuatan dan analisis mutu yoghurt. Buletin Teknik Pertanian 11(1): 12-16. 